\title{
Biological Treatment of Wastewater from Production Enterprises
}

\author{
Buriev Sulaymon Burievich ${ }^{1} \&$ Yuldoshov Laziz Tolibovich ${ }^{1}$ \\ ${ }^{1}$ Bukhara State University, Bukhara, Uzbekistan \\ Correspondence: Buriev Sulaymon Burievich, Bukhara State University, Bukhara, Uzbekistan. E-mail: \\ azizqobilov-87@mail.ru
}

Received: December 12, 2019

Accepted: March 19, 2020

Online Published: May 5, 2020

doi:10.5539/ijb.v12n3p14

URL: doi: 10.5539/ijb.v12n3p14

\begin{abstract}
The article provides information on the growth, development, reproduction and degree of purification of wastewater from organo-mineral substances of the high water plant pistia (Pistia stratiotes L) oil refining plant wastewater.
\end{abstract}

Keywords: High Water Growth, an Increase in the Runway (Runway Stratiotes L), Biomass, Oil Plant, Wastewater, Pollution, Dissolved Oxygen in Water, Organic and Mineral Substances

\section{Introduction}

At present, the water problem in the world is considered an urgent problem. This is also the amount of water needed for them as a result of the increase in production and industrial enterprises. In the technological processes of enterprises, various products are developed, and a certain part of them fall into the waters, which leads to water pollution. As a result of the excretion of organic substances (petroleum products, dye substances, proteins, carbohydrates, etc.) in the water, leaky waters are formed in connection with the oxidation of the oxygen contained in the water, their consumption.

Flowing waters are divided into the following types:

One of them. From the communal economy (household) - kitchens, washing machines, and running water coming out of the baths.

Two. From the sphere of production - wastewater contaminated with various substances, which are used in the production process.

The three. On the account of atmospheric precipitation, the formed sized waters-rain and snowy population punk, or flowing waters formed as a result of the washing of the territory of the enterprise.

The methods of cleaning the wastewater have been established.

One of them. Mechanical method (grinding, deposition, filtration, centrifugation), etc. G2.Physico-chemical method (adsorption, coagulation, flocculation, ion exchange, extraction)

The three. Chemical (reagent) method (neutralization, oxidation. reduction)

The four. Biochemical method (aerobic, anaerobic conditions)

The five. Thermal methods (flame cleaning in the presence of high temperatures)

The six. Biological method (with the help of plants)

The most useful among these methods is the biological method. Currently, in the world experience, specialized in the treatment of various wastewater treatment systems, which include purification methods, has been created. (Khodzhiev, 2019) industrial and other manufacturing enterprises are obliged to throw sewage pipes only after primary cleaning of wastewater contaminated with toxic chemicals. But some businesses are also releasing direct leaking water without cleaning or after a leaky gutter. This leads to disruption of the environment and ecology.

When cleaning by biological method, we clean water using several water plants. Of these, ryaska, azolla, pistia, plants are used. From high water plants, growers (ryaska, azolla, pistia, etc.) on the surface of the water are used in various branches of the national economy. The above plants are rich in physiologically active substances. To reproduce them, a large amount of mineral nutrients is required. Plants that are rich in carbohydrates, proteins, vitamins and other substances are being sown in wastewater from cities and production enterprises as well as 
agriculture in order to obtain and cheapen a large amount of biomass, and their level of purification of wastewater from various impurities is being studied.

Today, a lot of work is being done at Bukhara State University on biological purification. In the experiments of our scientists used the wastewater of the oil refinery.

The wastewater of the oil refinery contains various poisonous substances-naphthenic acid, me canines, nitrogen and sulfur compounds, phenols, hydrogen supplied, arsenic and others (Lubovich, 1977). If the wastewater with such a composition is thrown into nature, it is dangerous for human life, including plants, animals, soils. Biological methods of purification of Okawa water, which preserve petroleum products, have been created (Buriev, Rashidov, Khaitov, \& Khodzhiev, 2009).

Two variants of experiments were carried out in laboratory conditions by bringing out wastewater from the karavulbazar oil refinery into 20-liter circulating and square-shaped Aquariums. The physico-chemical composition of The brought wastewater was determined. Petroleum products containing wastewater contain 190 $\mathrm{mg} / \mathrm{l}$, the amount of oxygen dissolved in water is absent. Because oxygen is spent on oxidation of organic substances in water. Biochemical expenditure of oxygen (KBS5)-255,5 mg02/1; the degree of oxidation was 150,5 $\mathrm{mg} 02 / \mathrm{l}$, the amount of ammonia was $5,5 \mathrm{mg} / 1$, nitrites-0,02 mg/l, nitrates- $4,0 \mathrm{mg} / 1$, sulfates- $137 \mathrm{mg} / 1$, chlorides-118 mg/l. (Figure 1).

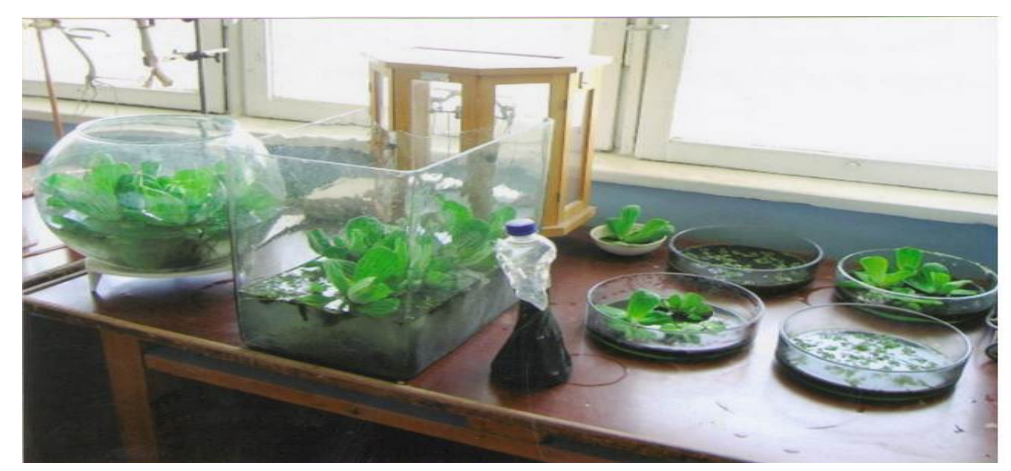

Figure 1. propagation of Pistia stratiotes in the laboratory

The amount of petroleum products in the water decreased to $13,7 \mathrm{mg} / \mathrm{l}$ in connection with the decomposition under the influence of bacteria and the conversion into mineral substances. (Table 1)

Table 1. Chemical composition of oil slurry plant wastewater

\begin{tabular}{|c|c|c|c|c|}
\hline \multirow{2}{*}{ Pointers } & \multirow{2}{*}{$\begin{array}{l}\text { Composition of } \\
\text { wastewater }\end{array}$} & \multirow{2}{*}{$\begin{array}{l}\text { Composition of wastewater at the end of } \\
\text { the experiment }\end{array}$} & \multicolumn{2}{|c|}{ Biomass of the plant $\mathrm{g} / \mathrm{m}^{2}$} \\
\hline & & & Beginning & Ending \\
\hline Temperature & 25,0 & 26,5 & 300 & 686 \\
\hline pH- & 6,5 & 7,5 & & \\
\hline Color & Magenta & White & & \\
\hline Smell & 5,0 & 1,0 & & \\
\hline Ingredients мг/л & 142 & 44,4 & & \\
\hline Oxygen, мг/л & Йўқ & 4,8 & & \\
\hline 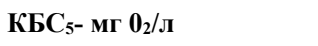 & 255,5 & 88,3 & & \\
\hline Oxidation - мг0 $0_{2} / л$ & 150,5 & 34,2 & & \\
\hline Ammonium, мг/л & 5,5 & no & & \\
\hline Nitritium, мг/л & 0,02 & no & & \\
\hline Nitrogenium,мг/л & 4,0 & no & & \\
\hline Sulphates, мг/л & 137 & 112,5 & & \\
\hline Chlorides, мг/л & 118 & 94,2 & & \\
\hline Petroleum products, мг/л & 190 & 13,7 & & \\
\hline
\end{tabular}


The experiments were continued and experiments were conducted, diluting the water with water in a ratio of 1:1 ( $50 \%$ aqueous $-50 \%$ water of the water of the water of the water of the hydropower) due to the fact that the plant of the grows and is not active in the wastewater. A pistachio plant was planted in the amount of $300 \mathrm{~g} / \mathrm{m} 2 \mathrm{for}$ aquariums, its development was observed. During the experiment, 3 times water temperature, $\mathrm{pH}$-measured every day. $50 \%$ of water is diluted with water and pistachio plant is planted in it, the yield and the degree of water purification are given in Table 2 .

Table 2. The chemical composition of waters of the oil processing plant is determined by the high water content of the plant on the (diluted in 1: 1 ratio)

\begin{tabular}{|c|c|c|c|c|}
\hline \multirow{2}{*}{ Pointers } & \multirow{2}{*}{$\begin{array}{l}\text { Composition of } \\
\text { wastewater }\end{array}$} & \multirow{2}{*}{$\begin{array}{l}\text { Composition of wastewater at the } \\
\text { end of the experiment }\end{array}$} & \multicolumn{2}{|c|}{ Biomass of the plant $\mathrm{g} / \mathrm{m}^{2}$} \\
\hline & & & Beginning & Ending \\
\hline Temperature & 26,0 & 26,8 & 300 & 850 \\
\hline pH- & 7,0 & 7,5 & & \\
\hline Color & Yellowish & Without color & & \\
\hline Smell & 3,0 & no & & \\
\hline Ingredients мг/л & 64,3 & 43,5 & & \\
\hline Oxygen, мг/л & 2,0 & 4,8 & & \\
\hline КБС & 147,5 & 31,8 & & \\
\hline Oxidation - мг02/л & 159,0 & 27,2 & & \\
\hline Ammonium, мг/л & 2,0 & no & & \\
\hline Nitritium, мг/л & 0,02 & no & & \\
\hline Nitrogenium,мг/л & 3,8 & no & & \\
\hline Sulphates, мг/л & 101,5 & 94,5 & & \\
\hline Chlorides, мг/л & 68,0 & 43,4 & & \\
\hline Petroleum products, мг/л & 98,5 & no & & \\
\hline
\end{tabular}

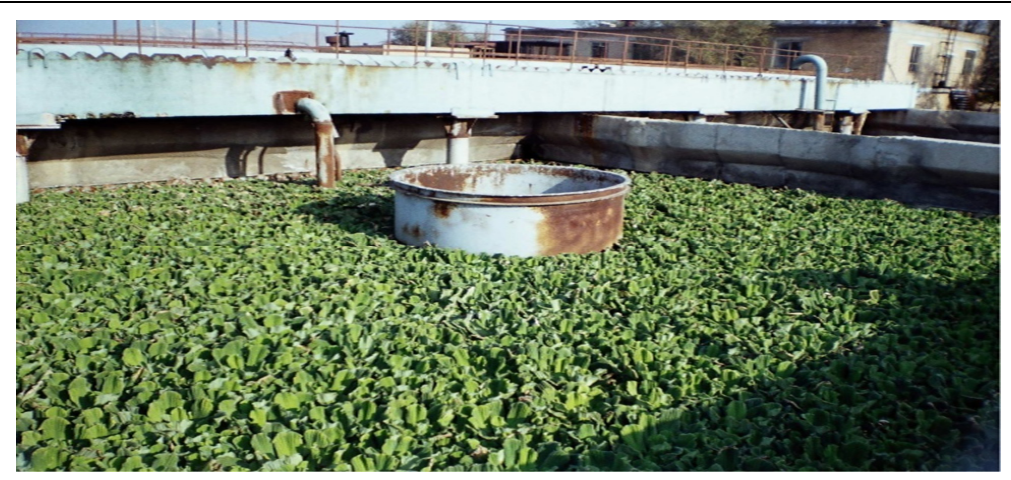

Figure 2. propagation of Pistia stratiotes to the enterprise

\section{Conflict of interests}

The authors declare that there is no conflict of interests regarding the publication of this paper.

\section{References}

Buriev, S. B., Rashidov, N., Khaitov, Yu. O., \& Khodzhiev, S. (2009). Koroulbozorsky oil refinery biotechnology wastewater treatment. Modern microbiology and biotechnology Problems (pp. 16-17). Materials of the Republican Scientific Conference. Tashkent.

Buriev, S., Rashidov, N., Hayitov, Y., \& Yuldoshov, L. (2011). Extraction of high water plants in the sewage treatment plants. Problems of biodiversity and rational use of flora of Uzbekistan. Samarkand.

Khodzhiev, S. O. (2019). Innovative technologies for wastewater treatment. Uzbekistan is industrialized for sustainable development in the regions. Navoi.

Lubovich, A. I. (1977). Water is sewn from pollution. Leningrad.

Lurie, Yu. Yu. (1984). Analytical chemistry of industrial sewage. M. 
Muzaffarov, A. M., Taubaev, T. T., \& Abdiev, M. (1970). The small duckweed and methods for their mass cultivation. Tashkent.

Stroganov, N. S., \& Buzinova, N. S. (1980). A practical guide to hydrochemistry. M.

Taubaev, T. T., \& Buriev, S. (1980). Biological wastewater treatment (p. 66). Tashkent.

Taubayev, T. T. (1970). Flora and vegetation of water bodies of Central Asia. Tashkent.

\section{Copyrights}

Copyright for this article is retained by the author(s), with first publication rights granted to the journal.

This is an open-access article distributed under the terms and conditions of the Creative Commons Attribution license (http://creativecommons.org/licenses/by/4.0/). 